\title{
On the characteristic and stability of iron diet supplements
}

\author{
Joanna Grzechulska-Damszel ${ }^{1 *}$, Agata Markowska-Szczupak ${ }^{1}$, Grzegorz Zolnierkiewicz ${ }^{2}$, \\ Janusz Typek ${ }^{2}$, Nikos Guskos ${ }^{2}$, Antoni W. Morawski ${ }^{1}$ \\ ${ }^{1}$ West Pomeranian University of Technology Szczecin, Faculty of Chemical Technology and Engineering, Piastów Ave. 42, \\ 71-065 Szczecin, Poland \\ ${ }^{2}$ West Pomeranian University of Technology Szczecin, Department of Physics, Piastów 17, 70-310 Szczecin, Poland \\ "Corresponding author: e-mail: joanna.grzechulska@zut.edu.pl
}

\begin{abstract}
The iron diet supplements: AproFER 1000 and AproTHEM were subjected to various chemical, microbial and magnetic analysis. The microbial analysis revealed no presence of pathogenic bacteria in the studied products. No significant changes in iron content or forms (bivalent/trivalent) were observed in EPR analysis of supplements stored at different conditions for a long period of time. The chemical and magnetic analysis showed that both AproFER 1000 and AproTHEM contain a high concentration of bivalent iron so they can be used as an iron diet supplements.
\end{abstract}

Keywords: iron diet supplements, magnetic analysis, chemical analysis, microbial analysis, supplements stability.

\section{INTRODUCTION}

Iron deficiency anemia is a worldwide health problem that affected not only less-developed countries but also remains a problem in developed countries. The lack of iron is the most common cause of anemia defined by inadequate amount of red blood cells or low hemoglobin or hematocrit in human population. However anemia is most prevalent complication in cancer patients and can develop in nearly half of patients with solid tumors and hematologic malignancies. Other negative consequences of iron deficiency on behavior, psychomotor development and growth rate are well established and underline the need to control iron levels ${ }^{1-7}$. Iron plays a vital role in oxygen metabolism, oxygen uptake and electron transport in mitochondria, energy metabolism, cell growth and differentiation, protein and neurotransmitter synthesis or enzyme functions. The daily iron need (for production of red blood cells and cellular metabolism) is about 25 $\mathrm{mg}$ per day. The vast majority of these is derived from recycling ageing erythrocytes in macrophages or iron-containing enzymes. Only 1 to $2 \mathrm{mg}$ of iron is absorbed from diet.

Dietary iron is available in two forms: ferrous iron $\mathrm{Fe}^{2+}$ and ferric iron $\mathrm{Fe}^{3+}$. Heme iron which is present in animal food sources, such as meat, poultry and fish is generally better absorbed than non-heme iron derived by vegetarian diet. For that reason the risk of iron deficiency is higher in populations preferring vegetarian eating styles. However there are several conditions that influence the loss of iron absorption. They include: chronic or significant weight loss and low intake of foods rich in ascorbic acid ${ }^{8}$. Because dietary intake is limited, iron supplements should be used to prevent and treat iron deficiency anemia. Lyophilized animal blood is a rich source of iron and proteins of high nutritional and functional quality.

Many kinds of iron supplements are produced from cull animal blood such as pigs, cows and etc. AproFER 1000 is a source of natural and high bioavailable iron produced after the digestion and separation of the enriched fraction of heme iron. AproFER 1000 is a heme iron concentrate. Heme iron is an excellent source of available iron to maintain increase hemoglobin levels.
Proper hemoglobin levels may reduce the risk of anemia. AproFER 1000 is a fine dark-colored powder with characteristic odor and taste. Iron in this product is mainly in bivalent form which is the best one to be assimilated by the human organism ${ }^{9-11}$. The bivalent iron is quickly oxidized to its trivalent iron, which when available in its free form can induce the formation of free oxygen radicals which may result in tissue damage ${ }^{12}$.

The body of an average man weighing $70 \mathrm{~kg}$ contains $4 \mathrm{~g}$ of iron complexes in a variety of proteins. As the complexes involving ions of the iron group have extended wave functions, they are very sensitive to any disturbance. A classic example is the copper complex in polyamine copper dinitrate, where minimal changes in the content of water molecules has a large impact on the electronic structure of the complex ${ }^{13}$. The above described processes have been studied intensively for years due to the abundant presence of free radicals and iron group ions complexes in blood ${ }^{14}$. A very effective method for study of dynamic phenomena is electron paramagnetic resonance (EPR), allowing to determine the concentration of magnetic centers and investigation of relaxation processes. It is particularly useful in the study of magnetic components in blood and in processes involving electron transfer ${ }^{15-27}$.

The aim of this work was to analyze a variety of parameters of AproFER 1000 and AproTHEM, like chemical, dynamic, static magnetic and microbial properties, iron diet supplements.

\section{MATERIAL AND METHODS}

\section{Material}

AproFER 1000 and AproTHEM are a heme iron concentrates. Heme iron is an excellent source of available iron to maintain / increase hemoglobin levels and can be used for oral administration of iron supplements as a natural source of iron.

AproFER 1000 is a source of natural high bioavailable iron produced after digestion and separation of the enriched fraction of heme iron. AproFER 1000 is a fine dark-colored powder with characteristic odor. 
The studied AproFER 1000 material was produced by Proliant company (Spain).

The main component of AproTHEM are the red blood cells obtained from animal blood. AproTHEM is a fine dark brown powder with characteristic odor and taste. The studied AproTHEM material was produced by Inter JJP company (Poland).

The above mentioned materials were used as iron supplements for clinical tests together with the placebo material being a beetroot powder. It was produced by Bomar company (Poland).

\section{FTIR and Total Iron Content Analysis}

The studied materials were subjected to FTIR analysis using Nexus FTIR spectrometer (Thermo Nicolet Corp., USA) with Golden Gate (ATR) attachment.

The analysis of total iron content in the studied iron supplement samples was made using ICP-OES method with Perkin Elmer Optima 5300DV analyzer. The samples of studied materials were mineralized before being subjected to ICP analysis.

\section{Microbial Properties}

The microbial stability of iron supplements (AproFER 1000, AproTHEM) and placebo was tested by own method based on method developed by The International Pharmacopoeia.

To establish a standard temperature of storage safety the iron supplements and placebo tablets blister were storage at $4^{\circ} \mathrm{C}, 25^{\circ} \mathrm{C}$ and $37^{\circ} \mathrm{C}$. The microbial test (separately for all used storage temperatures) were carried out under aseptic conditions in tree replications once a month for one year.

The following liquid media were used: Soyabean Casein Digest Agar SCDA (pancreatic digest of casein $17.0 \mathrm{~g}$, papaic digest of soyabean meal $3.0 \mathrm{~g}$, sodium chloride $5.0 \mathrm{~g}, \mathrm{~K}_{2} \mathrm{HPO}_{4} 2.5 \mathrm{~g}$, glucose $2.3 \mathrm{~g}$ in 1 liter of distilled water, $\mathrm{pH} 7.3 \pm 0.2$ ); Thioglycolate Broth TB (L-Cystine: $0.5 \mathrm{~g}$, sodium chloride $2.5 \mathrm{~g}$, yeast extract 5.0 $\mathrm{g}$, glucose $5.0 \mathrm{~g}$, peptone $\mathrm{K} 15.0 \mathrm{~g}$, sodium thioglycolate $0.5 \mathrm{~g}$, resazurin $0.001 \mathrm{~g}$, agar $0.75 \mathrm{~g}$ in 1 liter of distilled water, $\mathrm{pH} 7.1 \pm 0.2$ ).

The solid media were obtained by supplementation with 15 g Agar-Agar (BTL, Poland). The media were prepared according manufacture's (BTL, Poland) instruc- tions and distributed to $10 \mathrm{ml}$ test tubes. The vents of test tubes were closed by cotton wool and then sterilized in autoclave high-pressure saturated steam at $121^{\circ} \mathrm{C}$ for 20 minutes. The media were incubated for 14 days. If growth of microorganisms was not detected after that time the media were considered to be sterile.

A single tablet of selected AproFER 1000, Apro THEM and Placebo blister were placed in aseptic conditions to six tubes (for each tested variant) and once again were plugged by cotton wool. The test tubes were placed at incubator at $25^{\circ} \mathrm{C}$ (three test tubes with AproFER 1000, AproTHEM and Placebo tablets) and $37^{\circ} \mathrm{C}$ (three test tubes with AproFER 1000, AproTHEM and Placebo tablets) for $24 \mathrm{~h}$. Withdraw $0.3 \mathrm{ml}$ from each test tube and placed on appropriate solid media Soyabean Casein Digest Agar or Thioglycolate Agar. The Petri dishes were incubated at $37^{\circ} \mathrm{C}$ or $25^{\circ} \mathrm{C}$ respectively. The bacteria colony were counted.

Additionally, pathogenic bacteria test were conducted by commercial POLCARGO INTERNATIONAL SP Laboratory (Szczecin, Poland). The following parameters were determined: the presence of Salmonella spp., the presence of Escherichia coli, the presence of coagulase-positive staphylococci, the number of yeast and molds and the total bacteria count $\mathrm{TBC}$ at $30^{\circ} \mathrm{C}$.

\section{Magnetic Properties}

DC magnetization measurements were carried out using MPMS-7 SQUID magnetometer in 2-300 K temperature range and magnetic fields up to $70 \mathrm{kOe}$ in the zero-field-cooling (ZFC) and field cooling (FC) modes. The EPR spectra were recorded using a standard X-band Bruker E 500 spectrometer $(v=9.45 \mathrm{GHz})$ with magnetic field modulation of $100 \mathrm{kHz}$. The microwave power was $\mathrm{P}=$ $0.63 \mathrm{~mW}$. The measurements were performed in $4-290 \mathrm{~K}$ temperature range using an Oxford helium-flow cryostat.

\section{RESULTS AND DISCUSSION}

The obtained FTIR spectra are presented on Figure 1. As can be seen, spectra of Aprofer 1000 and AproTHEM samples are practically the same. The only difference is the intensity of peaks that can result from the hydration of the materials. AproFER 1000 is characterized by deeper degree of dehydration during the production process.

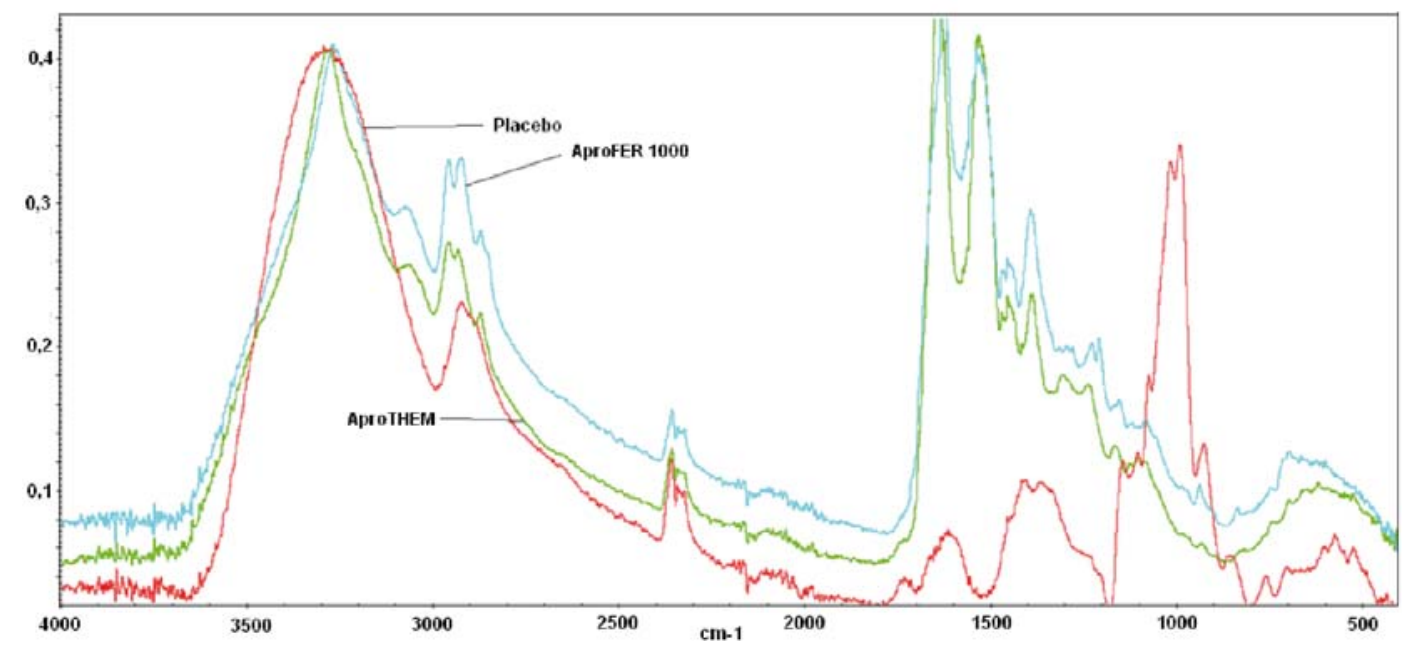

Figure 1. FTIR spectra of AproFER 1000, AproTHEM and Placebo 
The broad peak at about $3600-3000 \mathrm{~cm}^{-1}$ arises from $\mathrm{O}-\mathrm{H}$ stretching band of hydroxyls and bound water. It can be observed on both bloods and beetroot samples. The region at about $3000-2900 \mathrm{~cm}^{-1}$ mainly belongs to asymmetric $\mathrm{CH}_{3}$ and $\mathrm{CH}_{2}$ stretching of lipids. The $1700-1500 \mathrm{~cm}^{-1}$ region originate from amide bands. $1200-900 \mathrm{~cm}^{-1}$ is a "fingerprint" absorption region of carbohydrates and is strongly seen on beetroot spectra. Acids (maltic, citric, etc) show characteristic bands between 1500-1200 $\mathrm{cm}^{-1} \mathbf{2 8 - 3 1}$.

The ICP analysis was made using the calibration method with the emission line characteristic for the iron at $238 \mathrm{~nm}$. The amount of total iron in the analyzed samples was $0.02,0.4$ and $1.2 \%$ by weight for Placebo, AproTHEM and AproFER 1000, respectively.

There were no bacteria growth on Thioglycollate Agar (TA) plates, independently from culture temperature $\left(25^{\circ} \mathrm{C}\right.$ or $\left.37^{\circ} \mathrm{C}\right)$ or supplements storage temperature $\left(4^{\circ} \mathrm{C}\right.$ or $25^{\circ} \mathrm{C}$ or $\left.37^{\circ} \mathrm{C}\right)$. TA is a selective and differential culture medium for bacteria designed to selectively isolate human pathogenic bacteria such as: Staphylococcus aureus ATCC6538, Clostridium perfringens ATCC13124, Salmonella enteritidis ATCC13076. Our results were in agreement with results obtained by commercial POLCARGO INTERNATIONAL SP Laboratory. After one year of storage there were no pathogenic bacteria in tested iron supplements and placebo. The detailed results are presented in Table 1. The differences between iron supplements and placebo only for total bacteria count TBC at $30^{\circ} \mathrm{C}$ were observed.

The results obtained on Soyabean Casein Digest Agar (SCDA) presented higher differentiation. The used medium supports the growth of wide variety of organisms even that of fastidious ones such as Neisseria spp., Listeria spp. and Brucella spp., etc. Tryptone Soya Agar is recommended by various pharmacopoeias as sterility testing medium and antimicrobial preservative- effective test.

Analysis of bacteria colony number growth on SCDA medium incubated at $25^{\circ} \mathrm{C}$ or $37^{\circ} \mathrm{C}$ showed some patterns:

in first two months of storage the microbial stability of tested bacteria were very high. No bacteria growth were observed independently from initial storage temperature $\left(4^{\circ} \mathrm{C}\right.$ or $25^{\circ} \mathrm{C}$ or $\left.37^{\circ} \mathrm{C}\right)$,

- after one year of storage the highest total bacteria and mold number (CFU/g) in all tested iron supplements and placebo was obtained for samples stored at $37^{\circ} \mathrm{C}$, respectively the lowest was reported for samples stored at $4^{\circ} \mathrm{C}$,

- in placebo samples, independently from initial storage temperature $\left(4^{\circ} \mathrm{C}\right.$ or $25^{\circ} \mathrm{C}$ or $\left.37^{\circ} \mathrm{C}\right)$ the higher total bacteria and mold number $(\mathrm{CFU} / \mathrm{g})$ were observed $(6.0$ $\times 10^{2} \mathrm{CFU} / \mathrm{g}$ ),
- total bacteria and mold number $(\mathrm{CFU} / \mathrm{g})$ in iron supplements was lower than acceptable number, declared in microbial certificate provided by both lyophilized pig blood producers,

total bacteria and mold number $(\mathrm{CFU} / \mathrm{g})$ in placebo was lower than quality requirements that are expected for dry vegetables.

Figure 2 presents the temperature dependences of DC magnetic susceptibility $(\chi=M / H$, where $M$ is magnetisation and $\mathrm{H}$ an external magnetic field) in $\mathrm{ZFC}$ and $\mathrm{FC}$ modes for AproFER 1000 and AproTHEM. Figure 3 shows the dependence of magnetization on an external magnetic field measured at $2 \mathrm{~K}$. DC magnetization measurements have shown that the concentration of magnetic centers in AproFER 1000 is about 6 times greater than in AproTHEM (Figures 2 and 3). Magnetization of AproTHEM at high temperatures and in high applied magnetic fields is negative because the diamagnetism of

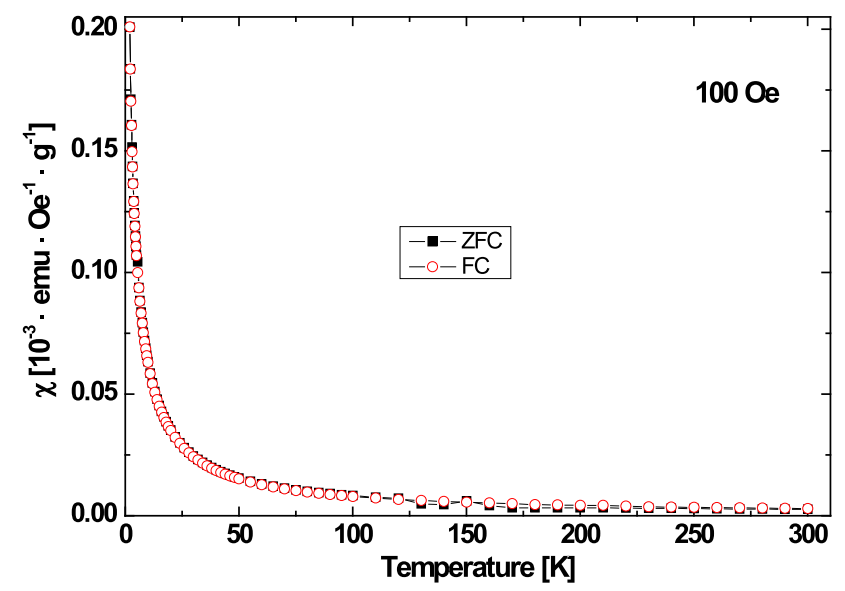

a) AproFER 1000

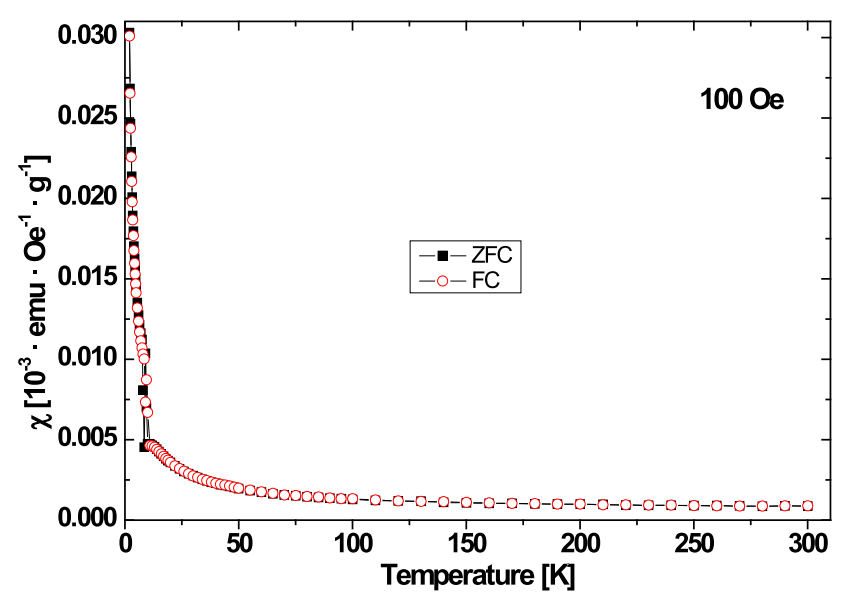

b) AproTHEM

Figure 2. Temperature dependence of magnetic susceptibility ( $\chi$ ), (a) AproFER 1000 at $\mathrm{H}=100$

Table 1. Selected microbial parameters of AproFER 1000, AproTHEM, and Placebo samples

\begin{tabular}{|c|c|c|c|}
\hline \multirow{2}{*}{ Microbial parameters } & \multicolumn{3}{|c|}{ Supplements } \\
\hline & AproFER 1000 & AproTHEM & Placebo \\
\hline The presence of Salmonella spp. & absent in $25 \mathrm{~g}$ & absent in $25 \mathrm{~g}$ & absent in $25 \mathrm{~g}$ \\
\hline The presence of Escherichia coli & absent in $1 \mathrm{~g}$ & absent in $1 \mathrm{~g}$ & absent in $1 \mathrm{~g}$ \\
\hline the number of yeast and molds & $<1.0 \times 10^{2} \mathrm{CFU} / \mathrm{g}$ & $<1.0 \times 10^{2} \mathrm{CFU} / \mathrm{g}$ & $<1.0 \times 10^{2} \mathrm{CFU} / \mathrm{g}$ \\
\hline total bacteria count TBC at $30^{\circ} \mathrm{C}$ & $<2.4 \times 10^{2} \mathrm{CFU} / \mathrm{g}$ & $<6.0 \times 10^{2} \mathrm{CFU} / \mathrm{g}$ & $<4.0 \times 10^{2} \mathrm{CFU} / \mathrm{g}$ \\
\hline
\end{tabular}

${ }^{*} \mathrm{CFU}$ - Colony-forming units are used to quantify results in many microbiological plating and counting methods 


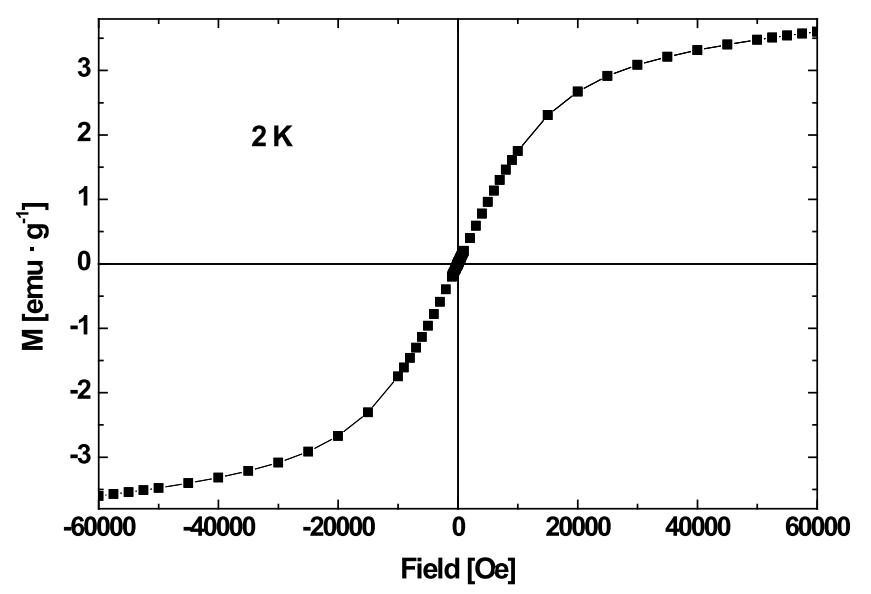

a) AproFER 1000

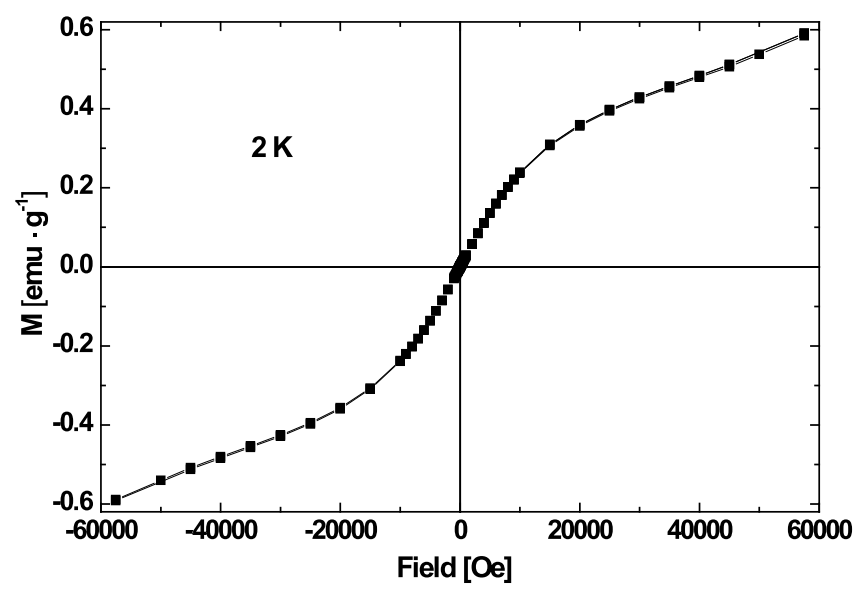

b) AproTHEM

Figure 3. Magnetic field dependence of magnetization (M) at $\mathrm{T}=2 \mathrm{~K}$, (a) AproFER 1000 and (b) AproTHEM

the capsule dominates over the paramagnetism of the sample. The $238 \mathrm{~nm}$ emission line characteristic of the iron has shown that in Placebo the iron concentration is 20 times smaller than in AproTHEM. The concentration of iron ions in AproFER 1000 is three times greater than in AproTHEM. DC magnetization measurements provided two times bigger concentration of magnetic centers which could be the consequence of different concentrations of divalent and trivalent iron complexes. It is not excluded that an additional magnetic response may arise from the free radicals or other complexes containing other magnetic ions such as divalent copper. The Curie-type behavior of temperature dependence of magnetic susceptibility, $\chi(T)=C / T$, was observed at low temperatures in both samples. Due to the competition of different interactions resulting from the existence of many types of magnetic centers (as will be demonstrated in EPR studies) a disordered magnetic state could be formed at low temperature ${ }^{32}$. Figure 3 presents the magnetic field dependence of magnetization taken at $\mathrm{T}$ $=2 \mathrm{~K}$ which confirms that AproFER 1000 has several times more magnetic centers. The dependence of magnetization on magnetic field registered at $\mathrm{T}=300 \mathrm{~K}$ showed that in AproTHEM the dominating contribution comes from the diamagnetic capsule. This also confirms that AproFER 1000 has much higher concentration of magnetic centers. The temperature dependence of ma- gnetic susceptibility in ZFC and FC modes showed no existence of the superparamagnetic state as $\mathrm{in}^{21}$.

Figure 4 shows the EPR spectra of AproFER 1000 and AproTHEM registered at different temperatures. As they are very complicated we will focus on the approach described in the work of Moreira et al. ${ }^{21}$ In addition other lines are also visible that occur due to the localized magnetic moments ${ }^{20}$. Some of them can be observed at high temperatures due to appropriate relaxation times (see inset in Fig. 4). In both samples a few different EPR components were observed at room temperature (Fig. 5 ) attributed to free radicals and transferrin (centered at $\mathrm{g}_{\text {eff }}=4.28(2)^{33,34}$. A broad resonance line centered at $g_{\text {eff }}=2.1$ is due to ferritin ${ }^{20}$. The difference between the number of magnetic centers registered in DC magnetization and EPR measurements might be explained by the fact that some complexes will be silent in one of these methods due to different relaxation times (long vs. short). Table 2 shows that hemoglobin and ferritin have significantly increased concentration in Aprofer 1000,

Table 2. The ratio of reduced integrated intensities

\begin{tabular}{|l|c|c|}
\hline & AproFER 1000 & AproTHEM \\
\hline $\mathrm{I} / \mathrm{I}(0)$ Hemoglobin & 1.88 & 1 \\
\hline $\mathrm{I} / \mathrm{I}(0)$ Transferrin & 0.31 & 1 \\
\hline $\mathrm{I} / \mathrm{I}(0)$ Free radicals & 0.95 & 1 \\
\hline $\mathrm{I} / \mathrm{I}(0)$ Ferritin & 2.00 & 1 \\
\hline
\end{tabular}

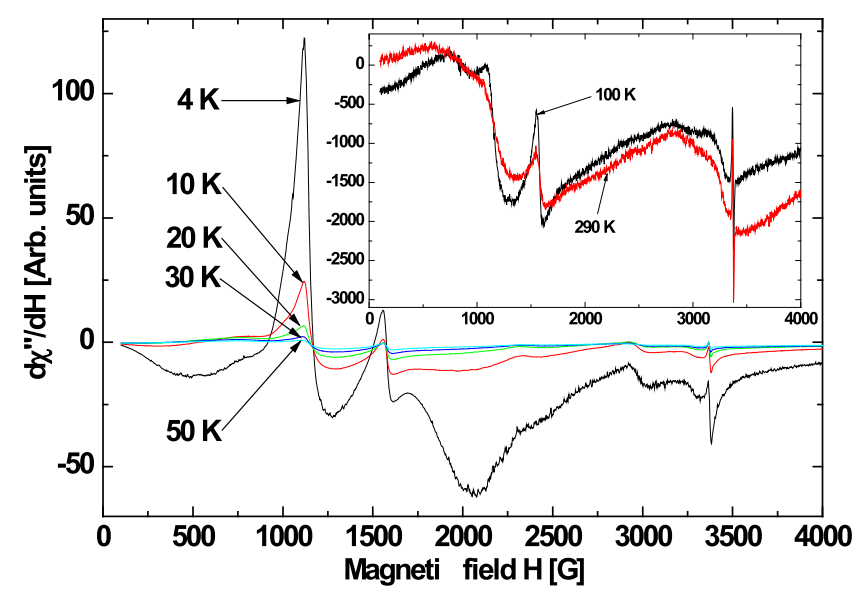

a) AproFER 1000

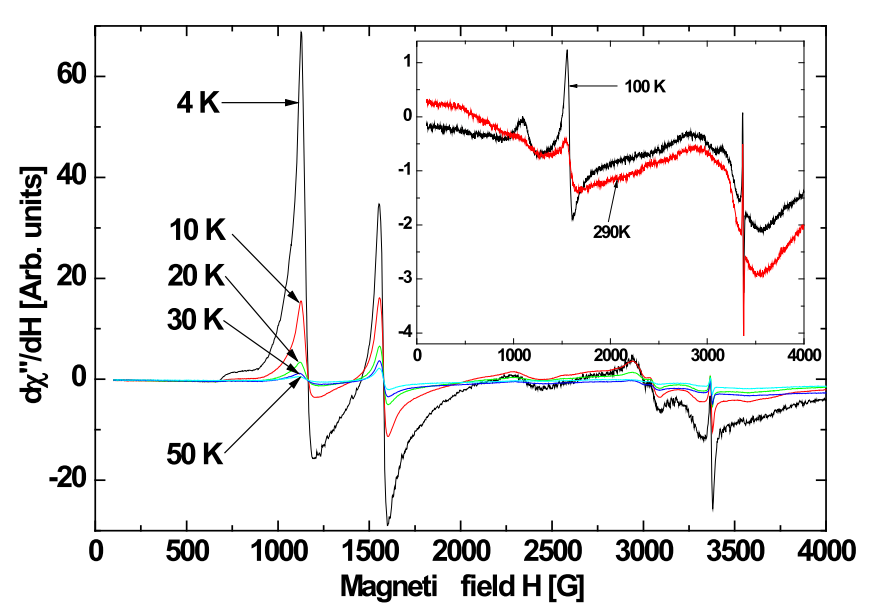

b) AproTHEM

Figure 4. Temperature dependence of the EPR spectra, (a) AproFER 1000 and (b) AproTHEM 


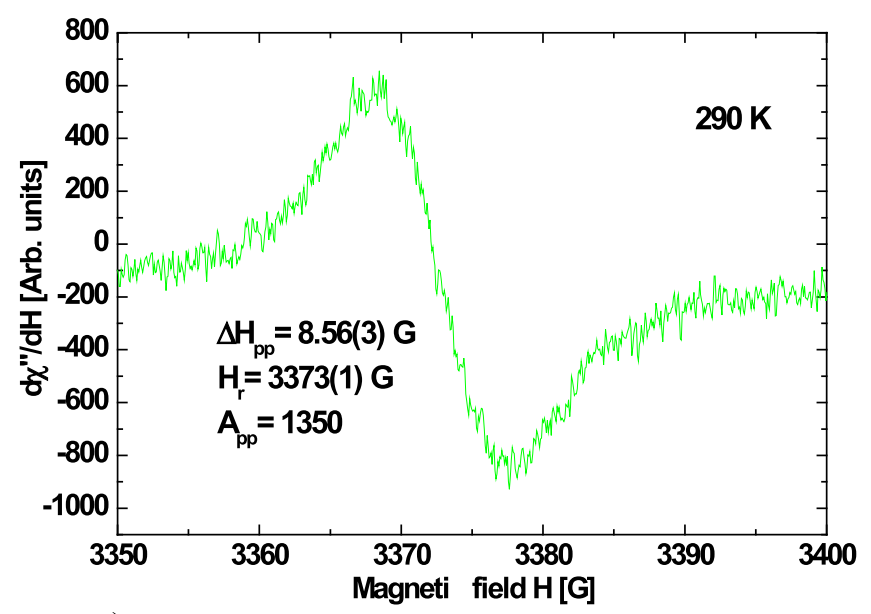

a)

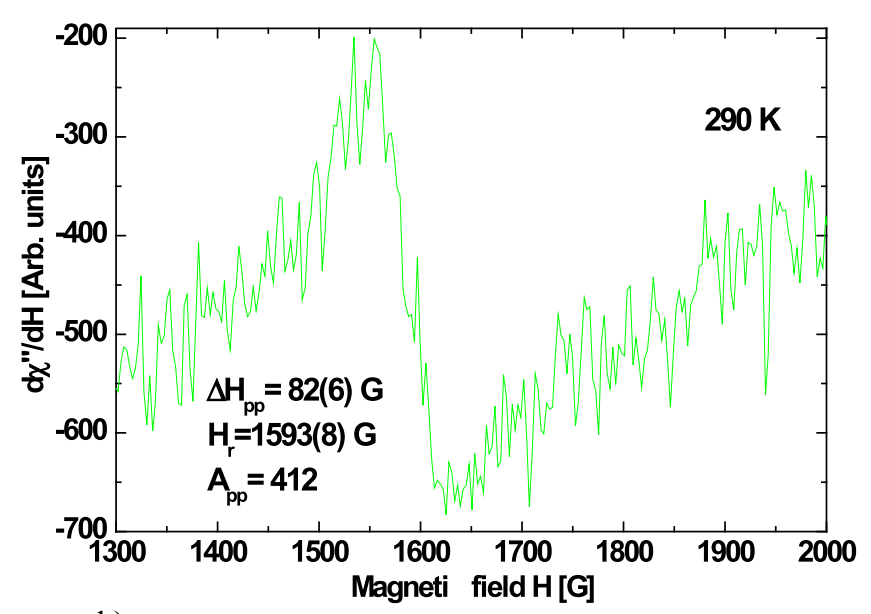

b)

Figure 5. The EPR spectra for AproFER 1000 at room temperature (RT); (a) free radicals and (b) transferrin

while an opposite effect is observed for transferrin and free radicals. The transferrin exhibits a characteristic three-component EPR spectrum near $\mathrm{g}_{\text {eff }}=4.3$ (159 $\mathrm{mT}$ ), flanked by exceptionally broad tails (Fig. 2 and figures in ${ }^{35,36}$ ).

Ferritin is associated with the oxidation of divalent to trivalent iron and plays an important role in the living matter ${ }^{37,38}$.

EPR measurements of the basic component showed a radical change in the amount of paramagnetic species being the result of oxidation of iron ions followed by the transition to a lower level of oxidization and thus significant change of the magnetic moment. It is not excluded that other components were taking part in this process. Additionally, an intense resonant signal at $\mathrm{g}_{\text {eff }}$ = 3.47 was observed in Aprofer 1000 (Fig. 4).

In hemoproteins, bis-histidine hemes having two axial histidine ligands displayed EPR spectra with $\mathrm{g}_{\text {eff }}$ values between 2.9 and $3.6^{22}$. The g-factor values of these complexes depend on the relative orientation of two imidazole rings and on the orientation of these imidazoles with respect to the porphyrin plane. Those rings are in an orthogonal conformation Type I hemichrome or HALS with iron low-spin complexes ${ }^{22,38}$.

Figure 6 shows the temperature dependence of the intensities of hemoglobin, transferrin and free radicals for AproFER 1000 and AproTHEM, respectively. Temperature dependence of the resonance line intensity

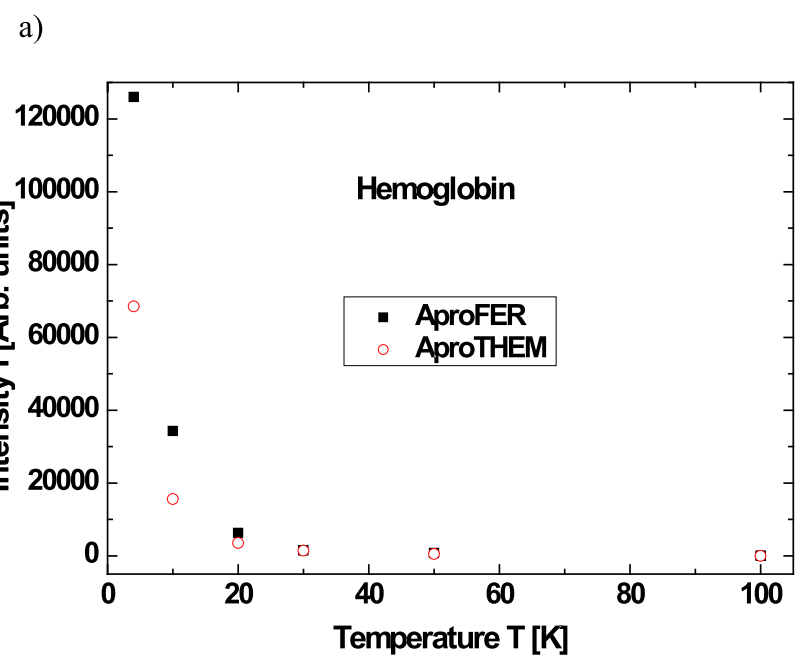

b)

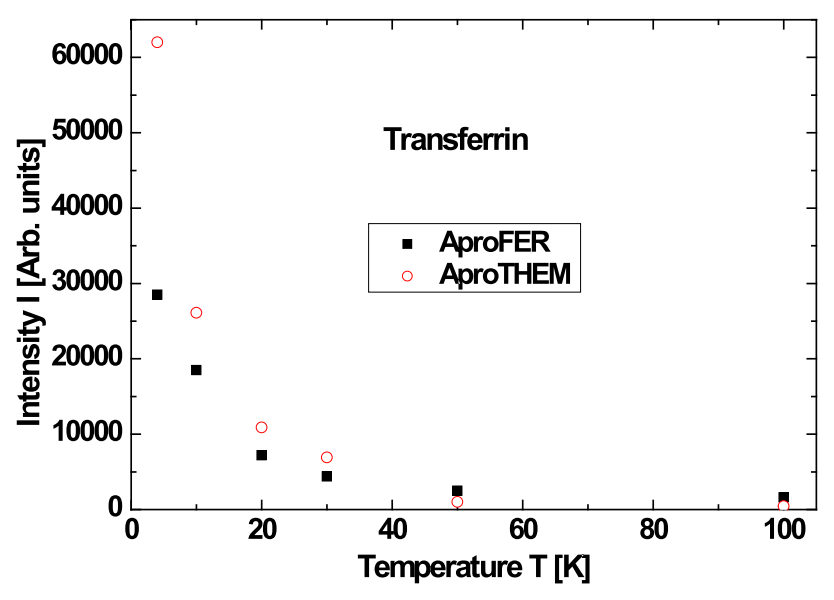

c)

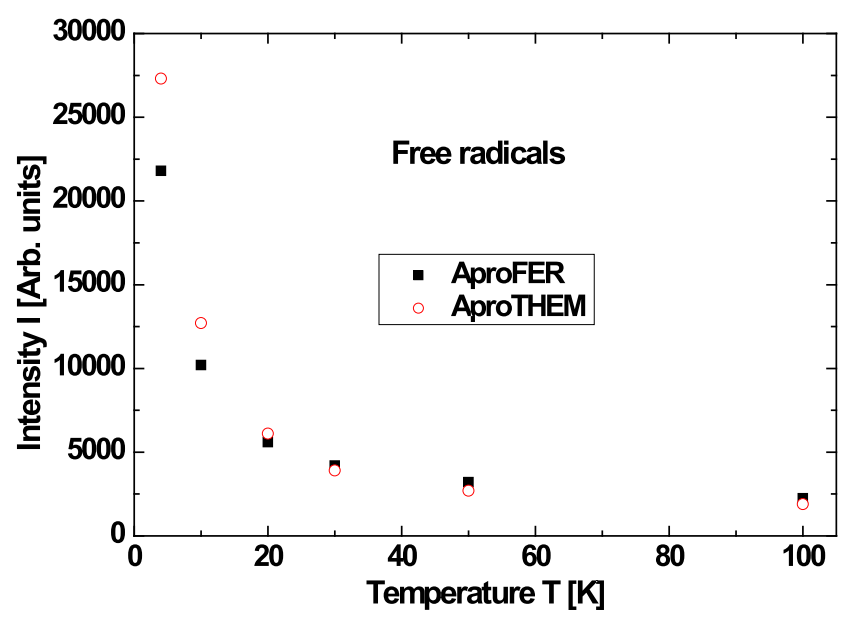

Figure 6. Temperature dependence of the intensities in AproFER 1000 and AproTHEM; (a) hemoglobin, (b) transferrin and (c) free radicals

indicate that the free radicals and complexes of trivalent iron ions change the relaxation time at low temperatures and the phenomenon is connected with dominate the spin-spin processes.

Figure 7 shows temperature dependence of the inverse intensities of the EPR spectra of hemoglobin, transferrin and free radicals in AproFER 1000 and AproTHEM, respectively. For hemoglobin and transferrin a ferromagnetic interaction is observed and opposite for free 

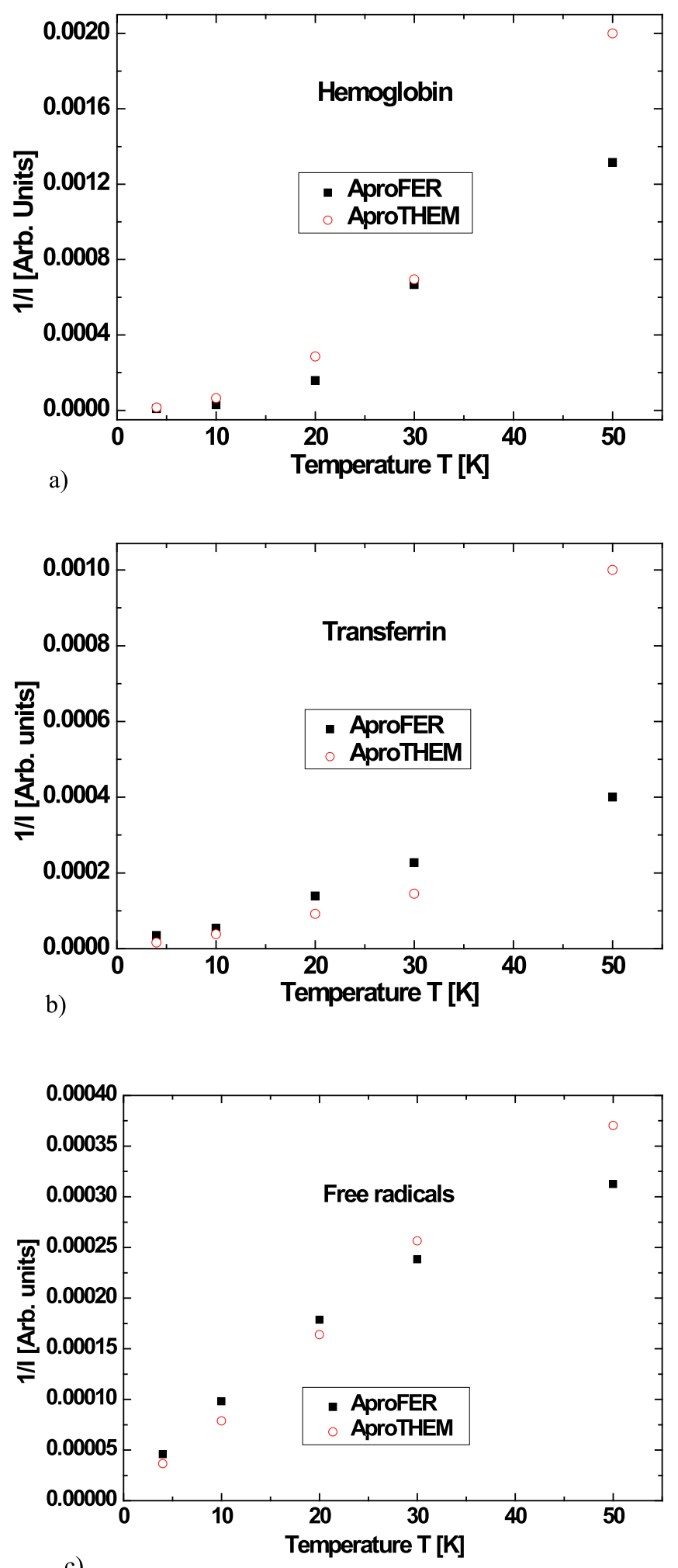

c)

Figure 7. Temperature dependence of the inverse intensities in AproFER 1000 and AproTHEM; (a) hemoglobin, (b) transferrin and (c) free radicals

radicals antiferromagnetic which is more intense at higher temperatures.

Studies of magnetic properties of blood often show the existence of the superparamagnetic state ${ }^{34}$. Most frequently the superparamagnetic state is observed in a system of non-interacting or weakly-interacting magnetic nanoparticles (or magnetic clusters). For high concentration of magnetic complexes an agglomeration phenomenon can occur that prevents formation of superparamagnetic phase.
The role of iron complex producing an EPR line at $\mathrm{g}_{\text {eff }}=3.47$ in AproFER 1000 is at present unknown.

Figure 8 presents the EPR spectra AproFER 1000 at $2 \mathrm{~K}$ stored at different temperatures $\left(4^{\circ} \mathrm{C}, 25^{\circ} \mathrm{C}\right.$ and $37^{\circ} \mathrm{C}$ ).It can be seen that there is no essential differences on the concentration of magnetic centers and spectra of all three samples are practically the same.

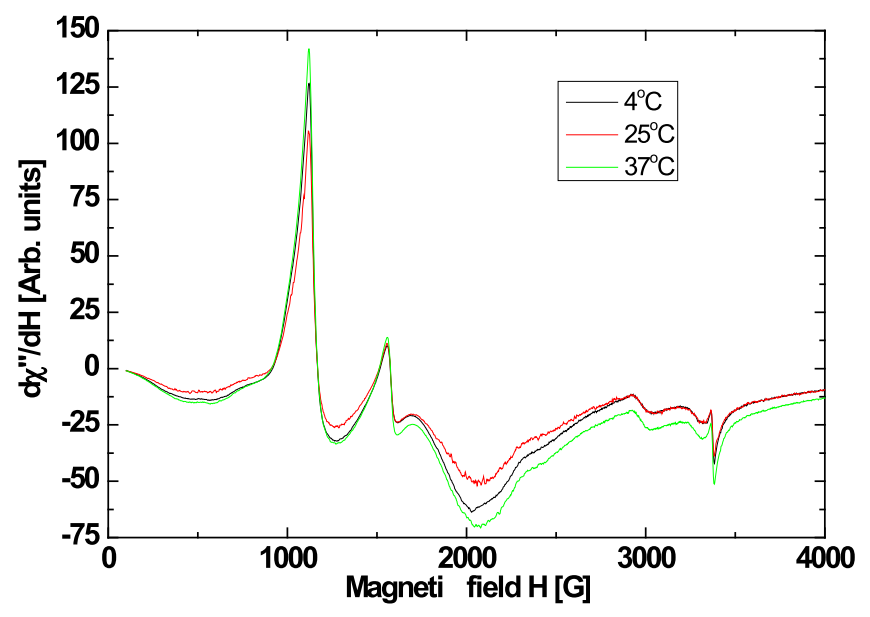

Figure 8. The EPR spectra AproFER 1000 at $4 \mathrm{~K}$ stored at different temperatures $\left(4^{\circ} \mathrm{C}, 25^{\circ} \mathrm{C}\right.$ and $\left.37^{\circ} \mathrm{C}\right)$

\section{CONCLUSIONS}

No significant changes were observed at the EPR spectra of AproFER 1000 stored at different conditions for 12 months. Although the growth of bacteria was observed on the iron supplement samples, the tablets content is used as a carbon or energy sources for saprophytic bacteria. Nonetheless no changes in iron content or forms were observed. There were no pathogenic bacteria on the supplements so they may be taken safely by patients with iron deficiency anemia.

The EPR studies showed a high concentration of iron in AproFER 1000 and AproTHEM products. It can be stated that this products is a rich source of bivalent iron and can be used as an iron supplement. Since AproTHEM shows very good solubility in water, opposite to AproFER 1000, it is more recommended for this application.

\section{ACKNOWLEDGEMENTS}

This work was supported by The National Center for Research and Development of Poland under project INNOMED/I/16/NCBR/2014.

\section{LITERATURE CITED}

1. Scholl, T.O. \& Reilly, T. (2000). Anemia, iron and pregnancy outcome, J. Nut. 130, 443S-447S. PubMed ID: 10721924.

2. Gray-Donald, K., Jacobs-Starkey, L. \& Johnson-Down, L. (2000). Food habits of Canadians: reduction in fat intake over a generation. Can. J. Public Health 91, 381-385. PubMed ID: 11089294.

3. Goddard, A.F., James, M.W., McIntyre, A.S. \& Scott, B.B. (2011) Guidelines for the management of iron deficiency anemia. Gut 60(10), 1309-1316. DOI: 10.1136/gut.2010.228874.

4. Landahl, G., Adolfsson P., Borjesson, M., Mannheimer, C. \& Rodjer, S. (2005). Iron deficiency and anemia: a common problem in female elite soccer players. Int. J. Sport Nut. Exerc. Metab. 15, 690-692.

5. Brion, M.J.A., Leary, S.D., Smith, G.D., McArdle, H.J. \& Ness, A.R. (2008). Maternal anemia, iron intake in pregnancy, 
and offspring blood pressure in the Avon Longitudinal study of parents and children. Am. J. Clin. Nut. 88, 1126-1133. DOI: 10.1093/ajcn/88.4.1126.

6. Melis, M.A., Cau, M., Congiu, R., Sole, G., Barella, S., Cao, A., Westerman, M., Cazzola, M. \& Galanello, R. (2008). A mutation in the TMPRSS6 gene, encoding a transmembrane serine protease that suppresses hepcidin production, in familial iron deficiency anemia refractory to oral iron. Haematologica 93, 1473-1479. DOI: 10.3324/haematol.13342.

7. Rohner, F., Woodruff, B.A., Aaron, G.J., Yakes, E.A., Lebanan, M.A.O., Rayco-Solon, P. \& Saniel, O.P. (2013). Infant and young child feeding practices in urban Philippines and their associations with stunting, anemia, and deficiencies of iron and vitamin A. Food and Nut. Bull. 34, 17-34.

8. Camaschella, C. (2015). Iron-Deficiency Anemia. N. Eng. J. Med. 72, 1832-1843. DOI: 10.1056/NEJMra1401038.

9. Quintero-Gutierrez, A.G., Mariaca-Gaspar, G.I., Villanueva-Sanchez, J., Polo, J., Rodrguez, C. \& Gonzalez-Rosendo, G. (2012). Acceptability and use of heme-iron concentrate product added to chocolate biscuit filling as an alternative source of a highly available form of iron. CYTA-J. Food 10, 112. DOI: 10.1080/19476337.2011.596284.

10. Huma, N., Salim-Ur-Rehman, Anjum, F.M., Murtaza, M.A. \& Sheikh, M.A. (2007). Food fortification strategy - preventing iron deficiency anemia: a review. Crit. Rev. Food Sci. Nut. 47, 259-265. DOI: 10.1080/10408390600698262.

11. West, A.R. \& Oates, P.S. (2008). Mechanisms of heme iron absorption: current questions and controversies. W.J. Gastroenterol. 14, 4101-4110. DOI: 10.3748/wjg.14.4101.

12. Andrews, N.C. (1999). Disorders of iron metabolism. N. Eng. J. Med. 341(26), 1986-1995. DOI: 10.1056/ NEJM199912233412607.

13. Guskos, N., Glenis, S., Likodimos, V., Typek, J., Fuks, H., Wabia, M., Szymczak, R., Lin, C.L. \& Perkowska, T.A. (2003). Influence of water molecule coordination on the magnetic properties of polyamine copper dinitrate complexes. J. App. Phys. 93(12), 9834-9838. DOI: 10.1063/1.1574593.

14. Kuriata, J., Sadlowski, L., Lipinski, E., Stawarczyk, W. \& Guskos, N. (1988). EPR Study of Cu(II) Ions in Caeruloplasmin, Acta Phys. Pol. A. 73, 543-546.

15. Brittenham, G.M., Sheth, S., Allen, C.J., Farrell, D.E. (2001). Noninvasive methods for quantitative assessment of transfusional iron overload in sickle cell disease. Semin. Hematol. 38, 37-56. PMID: 11206960.

16. Ost, T.W.B., Munro, A.W., Mowat, C.G., Taylor, P.R., Pesseguiero, A., Fulco, A.J., Cho, A.K., Cheesman, M.A., Walkinshaw, M.D. \& Chapman, S.K. (2001). Structural and spectroscopic analysis of the $\mathrm{F} 393 \mathrm{H}$ mutant of flavocytochrome P450 BM3. Biochemistry 40(45), 13430-13438. PMID:11695889.

17. Brittenham, G.M. \& Badman, D.G. (2003). Noninvasive measurement of iron: report of an NIDDK workshop. Blood. 101(1), 15-9. DOI: 10.1182/blood-2002-06-1723.

18. Canavese, C., Bergamo, D., Ciccone, G., Longo, F., Fop, F., Thea, A., Martina, G. \& Piga, A. (2004). Validation of serum ferritin values by magnetic susceptometry in predicting iron overload in dialysis patients. Kidney Int. 65(3), 1091-1098. DOI: 10.1111/j.1523-1755.2004.00480.x.

19. Ślawska-Waniewska, A., Mosiniewicz-Szablewska, E., Nedelko, N., Galazka-Friedman, J. \& Friedman, A. (2004). Magnetic studies of iron-entities in human tissues. J. Magn. Magn. Mater. 272-276, 2417-2419. DOI: https://doi.org/10.1016/j. jmmm.2003.12.843.

20. Huang, Z., Shiva, S., Kim-Shapiro, D.B., Patel, R.P., Ringwood, L.A., Irby, C.E., Huang, K.T., Ho, C., Hogg, N., Schechter, A.N. \& Gladwin, M.T. (2005). Enzymatic function of hemoglobin as a nitrite reductase that produces NO under allosteric control. J. Clin. Invest. 115(8), 2099-2107. DOI: 10.1172/JCI24650.

21. Moreira, L.M., Poli, A.L., Costa-Filho, A.J. \& Imasato, H. (2006). Pentacoordinate and hexacoordinate ferric hemes in acid medium: EPR, UV-Vis and CD studies of the giant extracellular hemoglobin of Glossoscolex paulistus. Biophys. Chem. 124, 62-72. DOI: https://doi.org/10.1016/j.bpc.2006.05.030.

22. Dunne, J., Caron, A., Menu, P., Alayash, A., Buehler, P.W., Wilson, M.T., Silaghi-Dumitrescu, R., Faivre, B. \& Cooper, C.E. (2006). Ascorbate removes key precursors to oxidative damage by cell-free haemoglobin in vitro and in vivo. Biochem. J. 399(3), 513-524. DOI: 10.1042/BJ20060341.

23. Moreira, L.M., Poli, A.L., Lyon, J.P., Saade, J., Costa-Filho, A.J. \& Imasato, H. (2008). Ferric species of the giant extracellular hemoglobin of Glossoscolex paulistus as function of $\mathrm{pH}$ : an EPR study on the irreversibility of the heme transitions. Comp. Biochem. Physiol. B 150 (3), 292-300. DOI: DOI:10.1016/j.cbpb.2008.03.020.

24. Krzyminiewski, R., Kruczynski, Z., Dobosz, B., Zaja, B., Mackiewicz, A., Leporowska, E. \& Folwaczna, S. (2011). EPR Study of Iron ion complexes in human blood. Appl. Magn. Reson. 40(3), 321-330. DOI: I 10.1007/s00723-011-0219-3.

25. Ibragimova, I., Chushnikov, A.I, Cherepnev, G.V., Petukhov, V.Y. \& Zheglov, E.P. (2014). EPR study of iron status in human body during intensive physical activity. Biofizika 59, 425-430. DOI: https://doi.org/10.1134/S000635091403008.

26. Davydov, R., Im, S., Shanmugam, M., Gunderson, W.A., Pearl, N.M., Hoffman, B.M. \& Waskell, L. (2016). Role of the Proximal Cysteine Hydrogen Bonding Interaction in $\mathrm{Cy}-$ tochrome P450 2B4 Studied by Cryoreduction, Electron Paramagnetic Resonance, and Electron-Nuclear Double Resonance Spectroscopy. Biochemistry 55(6), 869-883. DOI: 0.1021/acs. biochem.5b00744.

27. Folajtar, D.A. \& Chasteen, N.D. (1982). Measurment of nonsynergistic anion binding to transferrin by EPR difference spectroscopy. J. Am. Chem. Soc. 104(21), 5775--5780. DOI: 10.1021/ja00385a036.

28. Liu, H., Su, Q., Sheng, D., Zheng, W. \& Wang, X. (2017). Comparison of red blood cells from gastric cancer patients and healthy persons using FTIR spectroscopy. J. Mol. Struct. 1130, 33-37. DOI: https://doi.org/10.1016/j.molstruc.2016.10.019.

29. Chylińska, M., Szymańska-Chargot, M. \& Zdunek, A. (2016). FT-IR and FT-Raman characterization of non-cellulosic polysaccharides fractions isolated from plant cell wall. Carbohydr. Polym. 154, 48-54. DOI: 10.1016/j.carbpol.2016.07.121.

30. Romano, N., Santos, M., Mobili, P., Vega, R. \& Gómez-Zavaglia, A. (2016). Effect of sucrose concentration on the composition of enzymatically synthesized short-chain fructo-oligosaccharides as determined by FTIR and multivariate analysis. Food Chem. 202, 467-475. DOI: 10.1016/j. foodchem.2016.02.002.

31. Bureau, S., Ruiz, D., Reich, M., Gouble, B., Bertrand, D., Audergon, J.M. \& Renard, C.M.G.C. (2009). Application of ATR-FTIR for a rapid and simultaneous determination of sugars and organic acids in apricot fruit. Food Chem. 115, 1133. DOI: https://doi.org/10.1016/j.foodchem.2008.12.100.

32. Zolnierkiewicz, G., Guskos, N., Typek, J., Anagnostakis, E.A. Blonska-Tabero, A., \& Bosacka, M. (2009). Competition of magnetic interactions in $\mathrm{M}_{3} \mathrm{Fe}_{4} \mathrm{~V}_{6} \mathrm{O}_{24}(\mathrm{M}(\mathrm{II})=\mathrm{Zn}, \mathrm{Cu}, \mathrm{Mn}$, $\mathrm{Mg}$ ) compounds studied by EPR J. Alloys Compd 471, 28-32. DOI: https://doi.org/10.1016/j.jallcom.2008.03.109.

33. Weinstein, J.S., Varallyay, C.G., Dosa, E., Gahramanov, S., Hamilton, B., Rooney, W.D., Muldoon, L.L. \& Neuwelt, E.A. (2010). Superparamagnetic iron oxide nanoparticles: diagnostic magnetic resonance imaging and potential therapeutic applications in neurooncology and central nervous system inflammatory pathologies, a review. J. Cereb. Blood Flow Metab. 30, 15-35. DOI: https://doi.org/10.1038/jcbfm.2009.192.

34. Grady, J.K., Mason, A.B., Woodworth, R.C. \& Chasteen, N.D. (1995). The effect of salt and site-directed mutations on the iron(III)-binding site of human serum transferrin as probed by EPR spectroscopy. Biochem. J. 309, 403-410. DOI: 10.1042/bj3090403. 
35. Scullane, M.I., White, L.K. \& Chasteen, N.D. (1982). An efficient approach to computer simulation of EPR spectra of high-spin Fe(III) in rhombic ligand fields. J. Magn. Reason. 47(3), 383-397. DOI: https://doi.org/10.1016/0022-2364(82)90207-4.

36. Yang, A.S. \& Gaffney, B.J. (1987). Determination of relative spin concentration in some high-spin ferric proteins using E/D-distribution in electron paramagnetic resonance simulations. Biophys. J. 51(1), 55-67. DOI: doi: 10.1016/S00063495(87)83311-8

37. Zhao, G., Arosio, P. \& Chasteen, N.D. (2006). Iron(II) and hydrogen peroxide detoxification by human $\mathrm{H}$-chain ferritin. An EPR spin-trapping study. Biochemistry 45(10), 3429-3436. DOI: $10.1021 /$ bi052443r.

38. Duclund, L. \& Toftlund, H. (2000). Electron paramagnetic resonance characteristics of some non-heme low-spin iron(III) complexes. Spectrochim. Acta A Mol. Biomol. Spectrosc. 56(2), 331-340. DOI: https://doi.org/10.1016/S1386-1425(99)00243-7. 